Volume 1, Number 1, 2003, pp. 1 27

\title{
Logistics of Container Transport in the Yangtze \& Yellow Sea Regions
}

\author{
Jess Browning*
}

In the $21^{*}$ Century, a region's growth and prosperity will depend upon its intermodal transportation infrastructure and its ability to efficiently move goods, materials, and people within the system whether it be from origin to destination; from supplier to customer through the various levels of the supply-chain; or from point to point within the system. Planning for the future focuses on improving a region's intermodal transportation system efficiencies and infrastructure, its connection to other economies, and on the development of logistics institutions and facilities.

With China's rapidly developing economy and society, record numbers of new modern facilities such as airports, ports, highways, logistics parks and warehouses are being built. Along with this, companies have made extensive investments in information technologies and software to support the tremendous growth that has taken place in the logistics industry. The development and improvement of China's historic inland water transport system is essential to their continued future growth and prosperity. In Korea, past and present National Governments have emphasized the importance of developing a North East Asian Logistics and Business Hub in their region and have worked on strategies, which include water transport, as part of an important national agenda to that end.

This article looks at how trade flows in the Yangtze and Yellow Sea Regions and between China and South Korea might be enhanced by application of improved shipping methods in marine commerce that will promote economic growth in the region. The application of logistics practices and use of barges is explored for the movement of containers on inland and coastal waterways as well as in short sea shipping which could greatly facilitate the region's situation with respect to future economic growth.

\section{BACKGROUND}

A region's growth and prosperity in the 21 st Century will depend upon its intermodal transportation infrastructure and operations within the system-the regional transportation system's ability to efficiently move goods, materials, and people within the system whether it be from origin to destination; from supplier to customer through the various levels of the supply-chain; or from point to point within the system.

* Director Emeritus, Global Trade, Transportation, and Logistics Studies and Affiliate Professor, Civil \& Environmental Engineering, the University of Washington, 4927 NE Tolo Road, Bainbridge Island, Washington, USA. Phone: 206-842-5797, Fax: 206-842-4381, Email: jessb@u.washington.edu. 
In Northeast Asia, the deputy director of China's Development and Reform Committee states that the region extending from the Bo Hai area to the Yangtze River system is expected to be a new engine for economic growth.' Its potential needs to be enhanced, however, for integral development of the area, and planning for its future, needs to focus on improving the intermodal transportation system's efficiencies and infrastructure as well as better uses of logistics and supply-chain management practices.

There are three economic subdivisions in the Bo Hai area: The Liaodong Peninsula with Dalian as its open port and Northeast China as its hinterland; the Beijing-Tianjin-Hebei section, with Tianjin as the principal port; and Shandong Peninsula, with Qingdao as its major port and the peninsular area and part of East China as its hinterland. ${ }^{2}$ Adjacent to Qingdao and the Yellow Sea region lying just south a short distance is the Yangtze River System. Shanghai is the major port and its hinterland stretches all the way to Chonqing and includes the provinces of Hunan, Anhui, Hebei, Henan, Hubei, Hunan, Jiangsu, and Jiangxi. Currently $60 \%$ of China' s trade with the USA passes through Shanghai whereas the majority of China's trade with Korea passes through the ports of Qingdao, Tianjin, and Dalian. The Yellow Sea Region also includes North and South Korea as well as the "West" of Japan. Korea is positioning itself to be the business and logistics hub of Northeast Asia. Part of their success will depend upon regional trade agreements and the logistics of the movement of goods, materials, and people on the Yellow Sea. Busan and Kwangyang are the two major transshipment ports in Korea. Other coastal Korean ports serve as mostly as feeder and domestic ports with some direct international trade.

Feeder service in coastal shipping and inland water transport is a key element that needs consideration in Yellow Sea economic development. Short Sea Shipping (SSS) within and between hub ports in China and Korea is an important aspect of this feeder service as well as a means to service their coastal ports. Short sea shipping for bilateral trade and for domestic shipping can also reduce road and rail congestions in the two countries. The logistics of developing short sea shipping is challenging. This article will focus on two elements of short sea shipping: 1) the logistics challenges, and 2) the use of barges to move containers on inland and coastal waterways as well as on the sea within and between China and Korea.

With China's rapidly developing economy and society in the course of reform and opening up, record numbers of new modern facilities such as airports, ports, highways, logistics parks and warehouses are being built. Along with this, companies have made extensive investments in information technologies and software to support the tremendous growth that has taken place in the logistics industry. The development of their historic inland water transport system is essential to their continued future growth and prosperity.

\footnotetext{
'People's Daily, "Bohai Sea rim economic circle, a new economic engine," Beijing: Interview of Wang, Yiming, Deputy Director of China's State Development and Reform Commission, October 04, 2003.

2 Ibid.
} 
In Korea, past and present National Governments have emphasized the importance of developing a North East Asian logistics and business hub in their region and have worked on Pentaport ${ }^{3}$ strategies, which include water transport, as part of an important national agenda.

This article looks at how trade flows in the Yangtze and Yellow Sea Regions between China and South Korea might be enhanced by application of improved shipping methods in marine commerce that will promote economic growth in the region. The application of logistics practices and use of barges is explored for the movement of containers on inland and coastal waterways as well as in short sea shipping which could greatly facilitate the region's situation with respect to future economic growth.

\section{LOGISTICS PRACTICES}

Today's internationally competitive businesses work through strategically designed integrated global networks that can efficiently respond to demands from anywhere in the world. This strategy is now known as "global logistics" and "supplychain management”. In addition, growing environmental concerns require that logistics should not only be efficient; but should also contribute to sustainable development. ${ }^{4}$ Logistics and value added facilities along with improved intermodal transportation systems can also facilitate increased trade and economic growth within a given region.

Logistic management can be defined as, "the science of balancing the storage (stocks) and movement (flows) of inputs and outputs to meet demand, and minimize total cost while delivering increased efficiencies," ${ }^{6}$ The New Chinese-English Dictionary defines logistics as the "material flow or circulation of goods." Wang (2002) states that in an earlier version of the dictionary, it was defined as "rear services." 7 The more recent definition of logistics applies to this article.

\section{South Korea's Logistics Services}

The Incheon area is being developed to attract various logistics services for marine related trade such as stevedoring, assembly, processing, and packaging as well as other services.

${ }^{3}$ Pentaport is a concept developed at Inha University in Incheon, Korea for regional economic development that brings together a cluster of various services in the context of 5 ports-a business port, a techno port, leisure port, airports and sea port (2003).

4 OECD, "Source Industry, Services \& Trade," Abstract, August 2002.

5 Browning, Jess H., "Development of Logistics and Transportation Systems in Promoting Trade \& Economic Growth: Comparing Incheon and Seattle Areas," Korean Observer, Vol. 34, No. 3 Autumn 2003

- DOTARS, "Freight Logistics in Australia: an agenda for action," June 2002, p5 2002.

Wang, Yang, "China Logistics: Past, Present and Future," Atlanta: Georgia Institute of Technology, 
On the air cargo side, Incheon International Airport is being developed to boost a range of logistics businesses, notably stevedoring, transportation, warehousing, display, marketing, processing, parts supply, repair, finance and insurance. The Government of the Republic of Korea is working to develop Korea's human resource capacity in both logistics and business by developing the population's multilingual capabilities. The Ministry of Economy and Finance plans to make living conditions better for foreign residents by building schools, including five international schools, and three satellite campuses of foreign universities. Incheon University will move to Songdo New Town to support capacity building within the new Free Economic Zone. Inha University, which has the Graduate School of International Trade and Logistics as well as a new Center for Global Logistics Studies, will open the Asia-Pacific School of Logistics, funded by Ministry of Education.

\section{China's Logistics Services}

China has the largest manufacturing base in the world and is close to becoming the largest market in the world. China's economic expansion and accession into WTO is challenging its logistics industry. There has been tremendous growth in the logistics industry from one dominated by a few big state-owned enterprises, to the emergence of domestic and foreign companies as well as third party logistics service providers. There are also many small, local service providers, which usually consists of a few people with a single truck. ${ }^{8}$ To support economic expansion, record numbers of new modern transportation related facilities such as airports, ports, highways, logistics parks and warehouses are being built. Along with this, companies have made extensive investments in information technologies and software.

In a recent study of logistics providers in China ${ }^{9}$, many of those surveyed claimed that they offer total logistics solutions as well as traditional logistics services. Companies viewed one-stop and value added services as key ingredients to survival in the future. Table 1 shows that traditional services such as freight forwarding, transportation, warehousing and distribution accounted for most of their revenues. Most of the logistics providers in China have built extensive domestic networks, especially in Eastern China, and all of them have plans for future expansion. Road transportation is the preferred mode and the majority of those surveyed out-source transportation, but retain control over operations.

The survey states that warehousing is still at an early stage of development, with rudimentary facilities and limited use of modern information technology.

It is important to note, that domestic logistics providers are most concerned with the limited resources available for future expansion, while foreign logistics providers list policy restrictions and regulations as their biggest challenges.

8 Jim Dai, Shi-Jie Deng, Jihong Ou, Kwok-Leung Tsui, Yang Wang, Huiwen Zhang, Wang Derong, Liu Xiaohong and Li Rui "China Logistics Provider Survey," The Logistics Institute, National University of Singapore, 2002.

Jim Dai, Shi-Jie Deng, Jihong Ou, Kwok-Leung Tsui, Yang Wang, Huiwen Zhang, Wang Derong, Liu Xiaohong and Li Rui "China Logistics Provider Survey," The Logistics Institute, National University of Singapore, 2002. 
Both domestic and foreign providers agree that a shortage of logistics professionals and executives is one of the major concerns. ${ }^{10}$

Table 1. Logistics Service Offerings in China

\begin{tabular}{|c|c|}
\hline Services & Number and $(\%)$ of companies offering the service \\
\hline Warehousing & $27(93.1 \%)$ \\
\hline Distribution & $26(89.7 \%)$ \\
\hline Transportation & $25(86.2 \%)$ \\
\hline Total logistics solution & $25(86.2 \%)$ \\
\hline Insurance agent & $23(79.3 \%)$ \\
\hline Consolidation & $22(75.9 \%)$ \\
\hline Custom clearance & $22(75.9 \%)$ \\
\hline Freight forwarding & $22(75.9 \%)$ \\
\hline IT-Support & $22(75.9 \%)$ \\
\hline Inventory management & $22(75.9 \%)$ \\
\hline Order management & $21(72.4 \%)$ \\
\hline Packaging and repackaging & $20(69.0 \%)$ \\
\hline Import/Export & $19(65.5 \%)$ \\
\hline Express shipping & $18(62.1 \%)$ \\
\hline Assembly and installation & $16(55.2 \%)$ \\
\hline Financial services & $9(31.0 \%)$ \\
\hline
\end{tabular}

Source: The Logistics Institute, National University, Singapore (2003)

Fossey (2003) states that China's third-party logistics industry is in its infancy, but it is expected to grow on average by $20-25$ percent over the next five years. One example is Sinotrans Logistics. In order to integrate its logistics business, Sinotrans is focusing on developing long-term relationships with large customers that need integrated logistics services including inventory management and the timely delivery of products to multiple locations. They intend to increase their market share and profitability by increasing participation in a greater portion of the management of customer's supply chains. One aim is to provide their customers with one-stop services. 


\section{MARITIME TRADE: THE CASE OF SOUTH KOREA AND CHINA}

For most ports, it is said, "what comes in by sea must go out by land." Larger ships with faster discharge rates place increased stress on the land transport connections, and generate a need for faster and more efficient intermodal transfers. The demand for better port performance and increased investment in port facilities has led to changes in many countries' port policies resulting in a change in port/carrier relations. Traditionally ports mostly served local trade and marine carriers came to ports to pickup the cargo. An ESCAP (2001) report states that now, ocean carriers serve mostly regional rather than local trade, and feeder or intermodal service moves the cargo to the vessel." As trade increases shipping lines desire to move to economies of scale with larger ships serving fewer numbers of ports creating loadcenters. This puts ports and regions in competition to serve the larger vessels. Fewer ports serving these vessels places more demand on the landside transportation system, as noted earlier, to move containers to and from these load-centers. It also presents opportunities for developments in coastal and inland shipping.

\section{Container Shipping Between Korea \& China}

The major Chinese ports for trade between China and Korea are the ports of Tianjin, Qingdao, Shanghai, and Dalian. In Korea, the major container lines are calling at the ports of Busan and Kwanyang, while the car-ferry and general cargo ships are calling at Busan, Incheon and Pyungtaek. Container trade is divided between direct trade and transshipment trade. Direct trade refers to the import and export of containers between Korea and China and transshipment trade refers to containers that pass through the ports of both countries. The total container volumes between Korea and China increased from 613,000 TEU in 1996 to 1,090,000 TEU in 2000 (see table 2). Exports were 510,000 TEUs and imports were 680,000 TEUs. Korean carriers had $46 \%$ of the business with 500,000 TEU and China carriers have $28 \%$ with 300,000 TEUs. Others carriers had $13 \%$ with 140,000 TEUs. It is interesting to note that car-ferries also had $13 \%$ with 140,000 TEU. ${ }^{12}$

" ESCAP, "Regional Shipping and Port Development Strategies Under a Changing Maritime Environment," Maritime Policy Planning Model, 2001.

${ }^{12}$ Ibid. 
Table 2. Container Shipping Between Korea \& China (Unit TEU, \%)

\begin{tabular}{c||r|r|r|r|r|r}
\hline & Korean & \multicolumn{1}{c|}{ Chinese } & $\begin{array}{c}\text { Joint } \\
\text { Venture }\end{array}$ & $\begin{array}{c}\text { Third } \\
\text { Country }\end{array}$ & Car Ferry & Total \\
\hline \hline 1996 & 195,235 & 141,894 & 88,339 & 118,038 & 69,448 & 612,954 \\
\hline$\%$ & 31.8 & 23.1 & 14.4 & 19.2 & 11.3 & 100 \\
\hline 1997 & 269,965 & 182,270 & 79,382 & 116,301 & 86,408 & 734,326 \\
\hline 1998 & 355,915 & 198,859 & - & 99,488 & 77,979 & 732,241 \\
\hline 1999 & 450,532 & 252,008 & - & 108,725 & 115,574 & 926,839 \\
\hline 2000 & 500,163 & 303,277 & - & 140,462 & 142,592 & $1,086,494$ \\
\hline$\%$ & 46 & 27.9 & - & 12.9 & 13.1 & 100 \\
\hline Total & $1,771,810$ & $1,078,308$ & 167,721 & 583,014 & 492,001 & $4,092,854$ \\
\hline$\%$ & 43.2 & 26.3 & 4.1 & 14.2 & 12 & 100 \\
\hline
\end{tabular}

Source: MOMAF (2001)

Figure 1 shows changes in scheduled waterborne container shipping linking Chinese ports to East Asian countries and their own independently administrated regions. Links to most East Asia countries have been increasing except during the period of the financial downturn. All of these links indicate the "site and situation relationship" that East Asia countries have in trade with various ports of China. ${ }^{13}$

${ }^{13}$ Browning, Jess, "Development of Logistics and Transportation Systems in Promoting Trade \& Economic Growth: Comparing Incheon and Seattle Areas," Korean Observer, Vol. 34, No. 3, Autumn 2003. The author discusses the geographical concepts of SITE and SITUATION describes the Pentaport model as being able to enhance the Incheon Region's situation with regard to trade in North East Asia. 
Figure 1. Shipping Services Between China \& East Asia

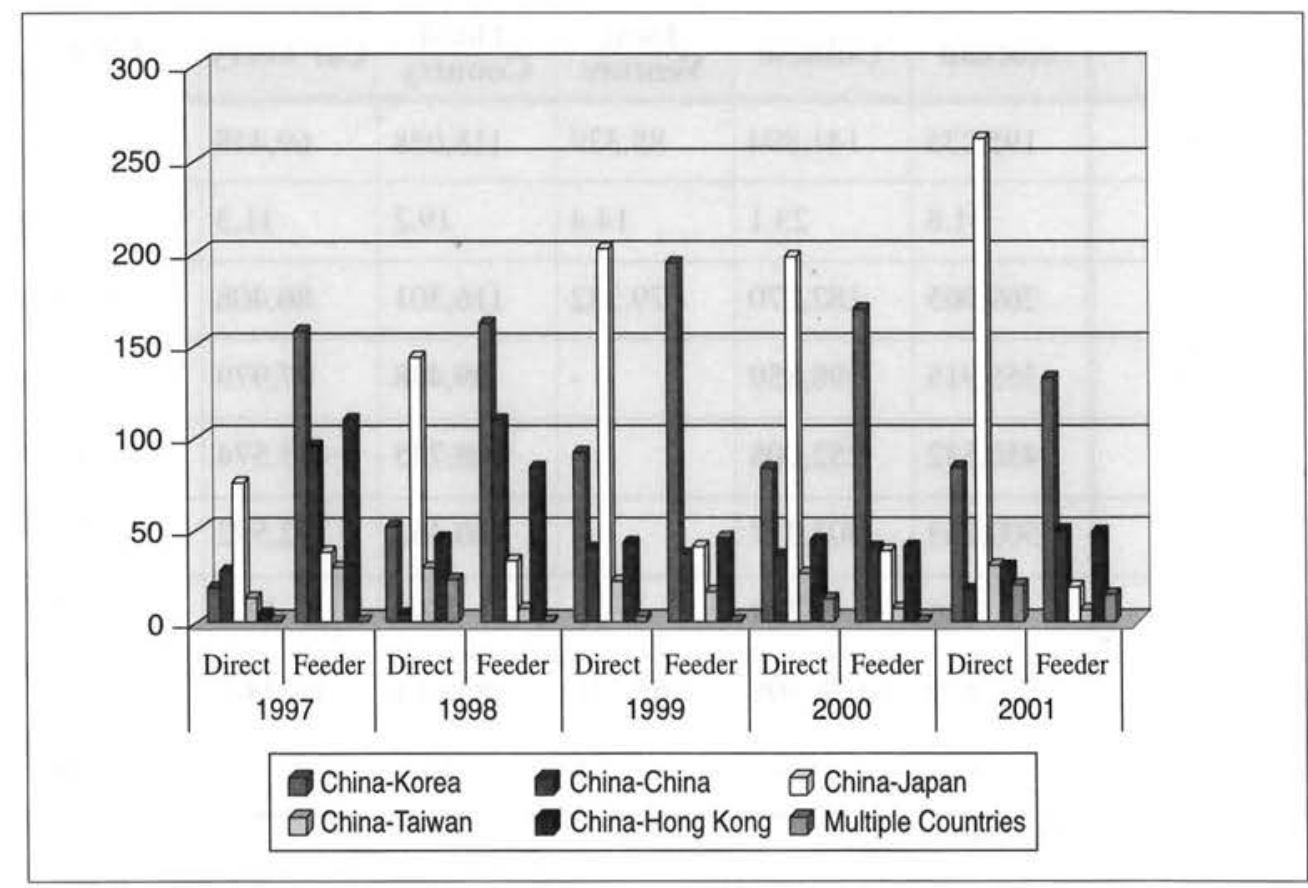

Source: China Shipping Gazette(2002)

\section{WORLD CONTAINER TRADE}

While the preceding figures are not too current, it can be seen in Figure 2 however, that world container volumes are increasing at a very rapid pace and that Asia trade is far ahead of the other world regions.

A recent UBS' s research report states that the container demand forecast in Asia for 2003 was growing by 6.8 per cent, and for 2004 by 7 per cent. This amounts to a total global container trade of 75 million TEUs this year and 80 million TEUs in 2004. For 2005, UBS is forecasting a 6.3 per cent growth to 86 million TEUs. ${ }^{14}$

Chang (2003) states that long-term trends in world history show that "While the Mediterranean Sea is the Sea of History and the Atlantic Ocean is the Sea of the Past Era, the Pacific Ocean is $\cdots$ not only Sea of the Present but also the Sea of the Future. Today the economies encompassed by the Asian Pacific Economic Cooperation (APEC) forum account for $50 \%$ of world trade and $65 \%$ of world gross domestic product (GDP). Northeast Asia is the core growth engine as the region contributed 17 $\%$ to world GDP in 2000 with the expectation of $30 \%$ in 2010 ."

\footnotetext{
${ }^{14}$ Shipping News, Donald Urquhart, Business Times June 24, 2003.
} 
Figure 2. World Container Volumes

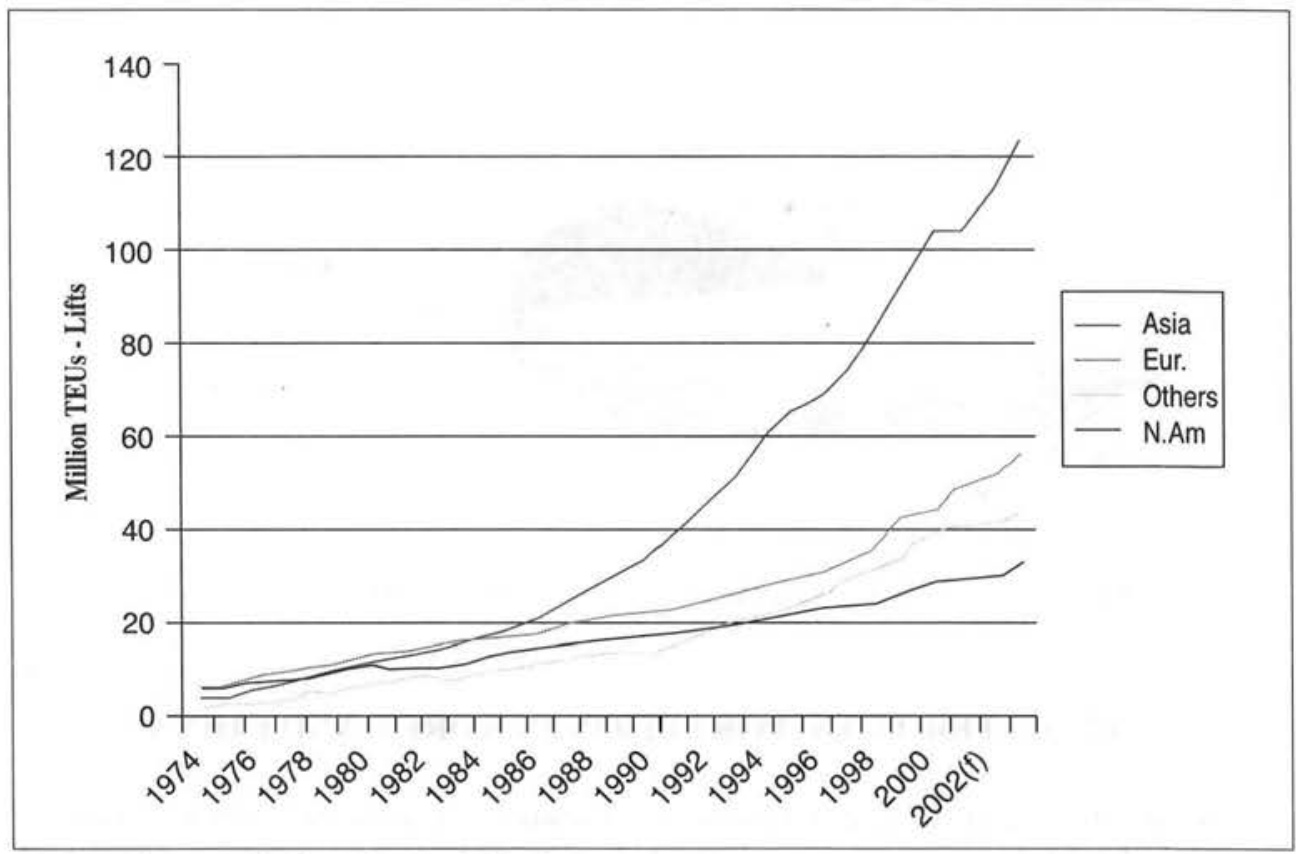

Data Source: Clarkson Research Studies

(CONTAINER INTELLIGENCE QUARTERLY, $4^{\text {th }}$ QUARTER 2002)

\section{TRANSPORTATION'S MODAL SPLIT IN KOREA AND CHINA}

In Korea, there is heavy dependence on roads to move containers causing congestion, pollution and other environmental problems. The modal split for containers in Korea (2001) was road transport $86.6 \%$, railway $11.0 \%$, and coastal shipping $2.4 \%$.

Chang (2003) states, "To resolve the problems related dependence on roads for cargo transport, the government is seeking to increase coastal shipping's proportion of the domestic transportation of containers."

In China the road is also the favored transportation mode as show in Figure 3. It accounts for $62 \%$ of the total transportation in terms of volume of goods. Although rail is the second most popular mode, it accounts for only about $15.5 \%$ of transportation. Inter-modal transportation is common. The results of a recent survey show that $83 \%$ of the companies practice inter-modal transportation at various levels. $^{15}$

is Jim Dai, Shi-Jie Deng, Jihong Ou, Kwok-Leung Tsui, Yang Wang, Huiwen Zhang, Wang Derong, Liu Xiaohong and Li Rui "China Logistics Provider Survey," The Logistics Institute, National University of Singapore, January 2003. 
Figure 3. Breakdown of Transportation Modes in China

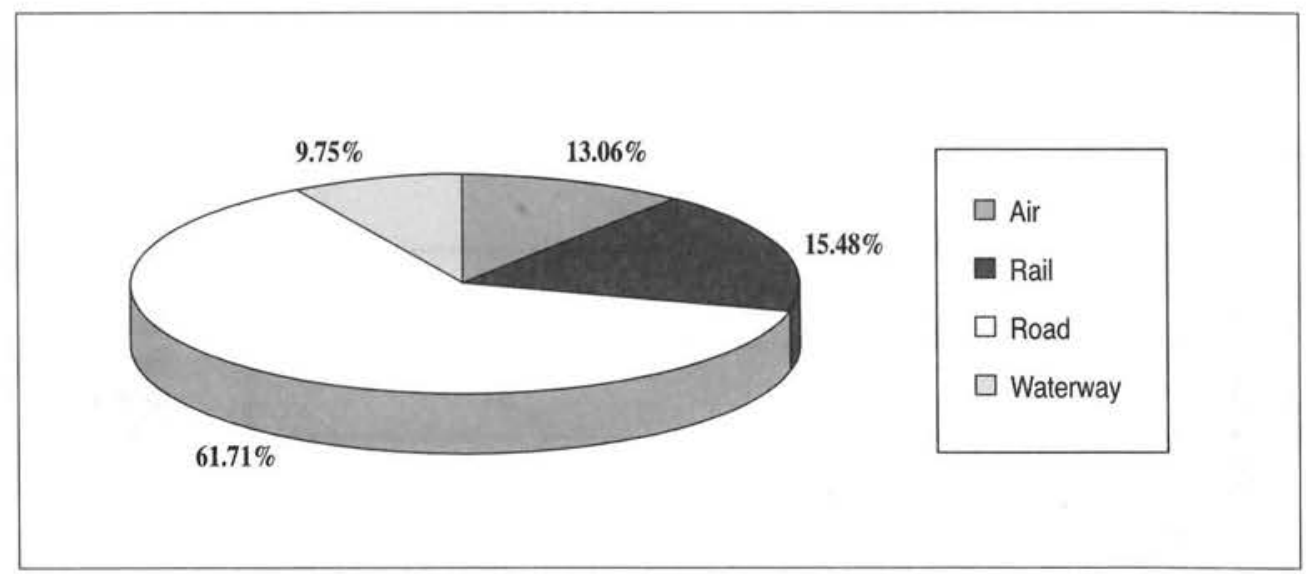

Source: The Logistics Institute, National University, Singapore (2003)

\section{WATER TRANSPORTATION IN KOREA AND CHINA}

The illustration in Figure 4 shows the Yangtze - Yellow Sea Region with its coastal and inland waterways, ports, and hub ports. Water transport by both coastal and inland waterways has tremendous potential for reducing both road and rail congestion as well as contributing to a more efficient and environmentally friendly system. Korea's Regional Research Center for Transportation System of the Yellow Sea (CTYS) at Inha University is involved in several related studies that involve short sea shipping. One is the development of a transportation system for sea-river shipping. This is aimed at developing an integrated sea-river transportation system to promote economic interaction within East and North East Asia.

Included in the Center's efforts will be the development of a sea-river container ship for trips between the Han River in Korea and the Yangtze River (and Han Jiang River) in China. ${ }^{16}$ These topics are also the focus of this article.

\section{South Korea Ports and Water Transport}

South Korea has $1,609 \mathrm{~km}$ of waterways that are currently restricted to mostly smaller vessels. Its ports and harbors include Busan, Chinhae, Incheon, Kunsan, Kwangyang, Masan, Mokp' o, P' ohang, Pyungtaek, Tonghae-hang, Ulsan, and Yosu. The Kyung-In 'canal project, which is under consideration, would provide an inland waterway on the west coast near Incheon that would connect to port facilities on the Han River within the Seoul metropolitan area. ${ }^{17}$

\footnotetext{
${ }^{16}$ Inha University, CTYS, http://ctys.inha.ac.kr/english/research.htm

17 World Fact Book, "Korea" January 1, 2003
} 
Nearly all containerized cargo enters or leaves Korea through the deep-water ports along the south and southeastern coasts. Busan is the largest and handled approximately $8,000,000$ TEUs in 2002 , which was about $82 \%$ of Korea's total. The ports along the west coast are generally less accessible to large ships. Incheon is the largest west coast port handling mostly bulk commodities and coastal container traffic. There is a large movement of containers between the Seoul area and Busan although as mentioned earlier, this trade is dominated by road transport. Factors driving Korea port development are at the national policy level. There is concern over logistics costs that are the principal drivers behind many transport infrastructure developments. These are reflected in the Korean ports sector by providing more container berths; meeting the demand for and increasing the coastal share of traffic in both containerized cargo and steel between the south coast and Seoul; and providing increased capacity to meet the demand for vessels carrying containerized cargo between Korea and other northeast Asian destinations.

Several new developments are proposed for Korea's west coast that are designed to handle increased Northeast Asia trade and coastal shipping. These include, as also mentioned earlier, the Kyung-In canal project which envisages a canal from a terminal on the west coast near Incheon connecting to terminals on the Han River within the Seoul metropolitan area; the extension of Incheon port (Incheon North Port); proposals for Incheon Songdo and Pyongtaek-Asan port; and the new Mokpo port project. ${ }^{18}$

\section{China Ports and Inland Water Transport}

China has long been recognized as a leader in inland water transport, with one of the world's largest navigable waterway systems. The Chinese have a long history, dating back to at least the seventh century, of using their inland waterways with the building of the Grand Canal in 610.

The 1,800-kilometer Grand Canal is the world' s longest man-made waterway connecting Beijing in the north and Hangzhou in the south. Since most of China's major rivers flow west to east, the Grand Canal, running north to south, is a critical route between the Yangtze River valley, the Yellow River valley and secondary river systems. ${ }^{19}$ Spear (1997) states that tremendous growth in international trade and rapidly expanding coastal shipping have severely strained China's port infrastructure. The main bottlenecks have been a shortage of deep-water ports, inadequate transport links, handling facilities and capacity at both inland and coastal ports as well as shallow river routes. The Huang $\mathrm{He}$ and $\mathrm{Hai} \mathrm{He}$ arenot navigable by larger vessels at their mouths on the Bo Hai. The national inland water transport system has been identified, however, as one means of relieving pressure on the overburdened road and rail systems.

\footnotetext{
18 Korea Times 2002/02/03

${ }^{19}$ Berger World, http://www.louisberger.com/berger/world/2000q4/asia.html
} 
Marine transport in China is divided into two major navigation zones: the northern and the southern ones. This article looks at the northern zone' s rivers that empty into the Bo Hai, the Yellow Sea, and the East China Sea. The major inland navigable rivers in Northern China are the Yangtze, the Heilongjiang (in the far northeast), the Huai He, the Han, the Xiang Jiang, the Gan, the Wei He, the Hai He, the Grand Canal between Beijing and Hangzhou, and the Qiantang estuary. The Yangtze is the most widely used waterway. Approximately $70 \%$ of the country's river passenger and freight traffic is on the Yangtze.

The Yangtze and its tributaries has $58,000 \mathrm{~km}$ of navigable length and 3,000 km of it is can be navigated by 1,000 dwt vessels. The Grand Canal can be navigated a distance of $1,747 \mathrm{~km}$ and is being expanded. There are about 2,000 inland ports, and of these 85 are major inland ports. Nanjing Harbor, the largest inland river harbor on the Yantze, has an annual capacity of 40 million tons. ${ }^{20}$ The average trip distance between inland ports is about $212 \mathrm{~km}$. Figure 4 shows (in parenthesis) the approximate distance between inland ports and Figure 5 shows the approximate distances of various inland ports to the sea. The ESCAP (2001) report states that containers volumes to and from major river ports on the inland waterway system grew from 100,000 TEU in 1990 to $1,880,000$ TEU in $1999 .{ }^{21}$

China's traffic and transportation network is expected to improve and become more efficient during the current five-year State transportation plan. At a recent press conference, the Vice-Minister of Communications, talked about development objectives set by his ministry for the 10th Five-Year Plan period (2001-05). Construction will take place on many road in the western region, in an effort to open land transportation passageways, which will connect regions, and inland areas with rivers and oceans, and China with neighboring countries.

Efforts are under way to continue developing Shanghai's status as an international navigation hub; accelerating construction of a fourth generation of container wharves in Shanghai, Ningpo, Dalian, Tianjin, and Qingdao; completing supporting freight distribution systems; renovating channels; focusing on construction projects of the Yangtze River mouth; and upgrading major coastal navigation hubs. ${ }^{22}$ For inland river ports, priority will be given to building multi-purpose and container berths at ports along the main waterway of the Yangtze River, including Chongqing, Wan Xian, Wuhan, Wuhu and Maanshan. The restructuring aims at improving handling between land and water modes of transportation and improving efficiency and sustainable development capacity of the whole transportation sector. ${ }^{23}$

\footnotetext{
${ }^{20}$ http://www.asianinfo.org/asianinfo/china/transportation.htm

${ }^{21}$ ESCAP, "Review of Developments in Transport and Communications in the ESCAP Region, 19962001 - Asia and the Pacific," 2001.

${ }^{22}$ Beijing Review, 2000, No. 52.

${ }^{23}$ Ibid.
} 
Figure 4. Inland Ports, Rivers \& Coastal Ports in the Yangtze-Yellow Sea Region

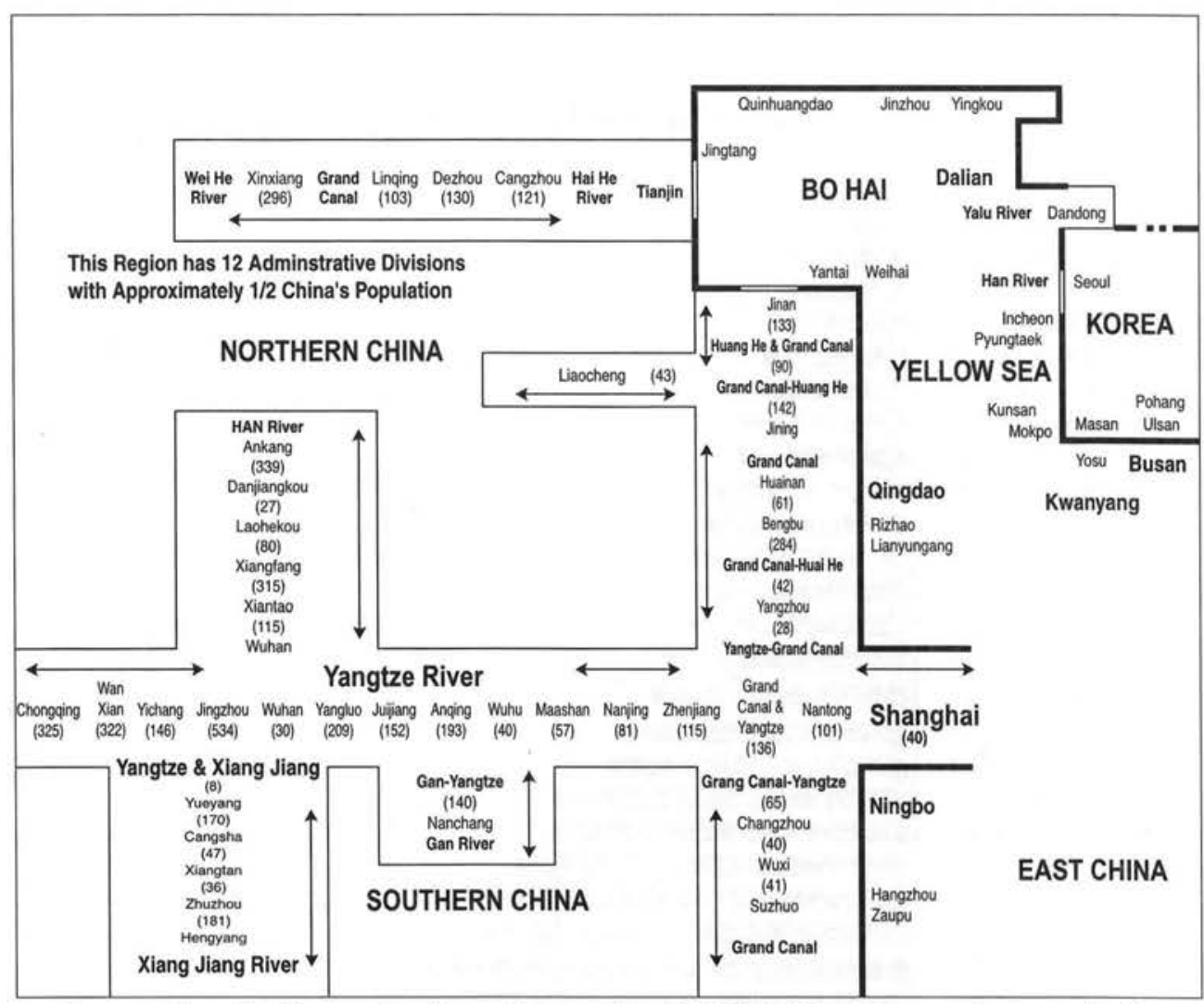

Source: Compiled by author from Encarta World Atlas(2000); Figures in parenthesis are approximate distances to next port 
Figure 5. Approximate Distance to the Sea for Some Inland Ports in China

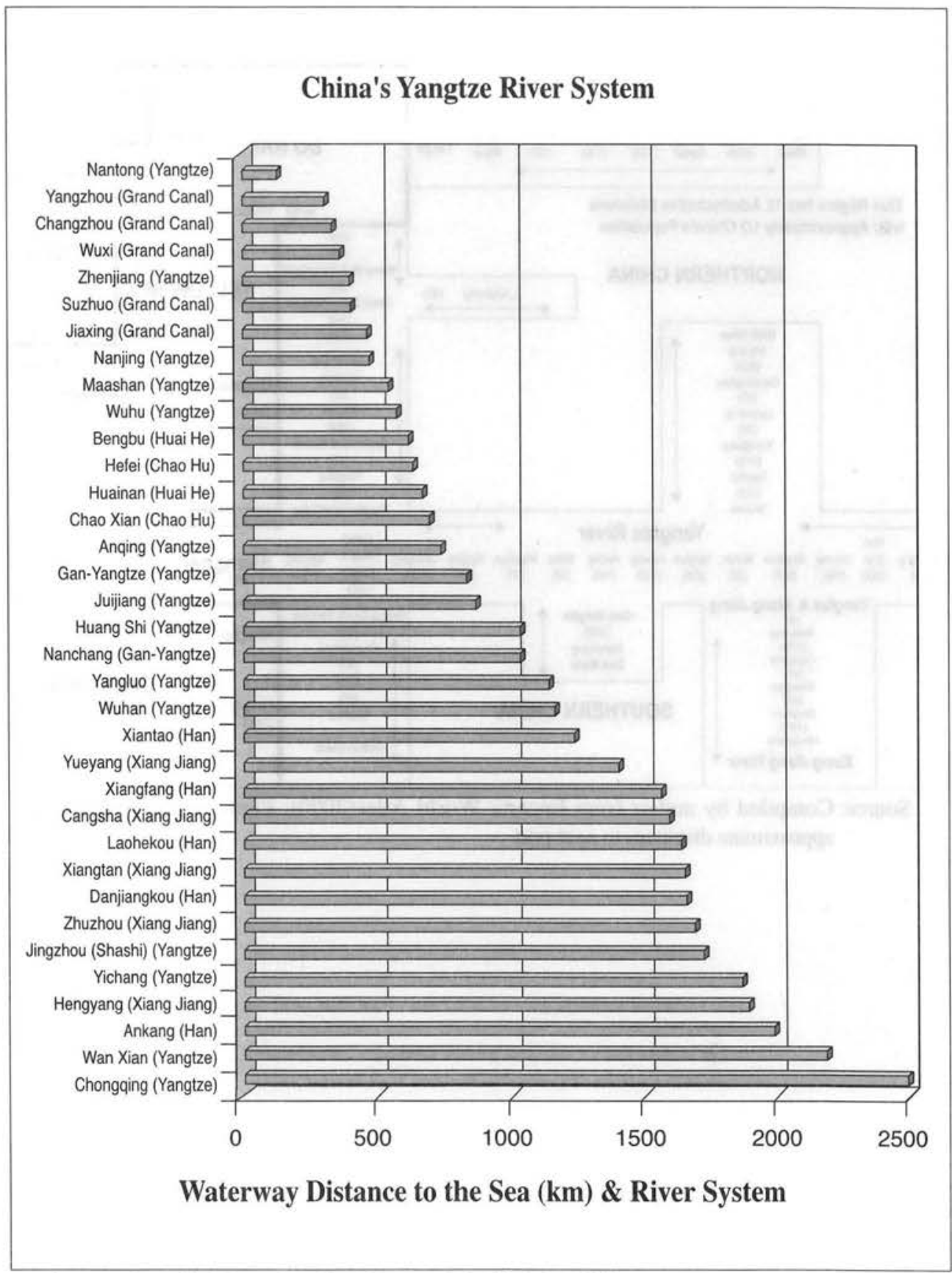

Source: Compiled by author from Encarta World Atlas(2000) 
Frankel (1997) states that due to limited road and railway networks in China, growing emphasis is being given to integration of intermodal transport with coastal and inland waterways that connect to hub ports for the shipping of containers.

While the rail network provides effective north to south transport capacity along the coast and in mid-China, and roads are increasingly used to connect large coastal cities with their surroundings. Only the three big navigable rivers, the Pearl (in the south), the Yangtze, and the Yellow rivers permit effective East-West transport and therefore economic development of China's vast interior whose population is largely concentrated along these three major river basins. China has the world's largest coastal and inland water shipping fleets but, in the past, these have not been coordinated and served only domestic point-to-point transfer.

Fossey (2003) states that while Shanghai is the main strategic hub for Central China, effective strategies for the entire country are increasingly important as the demand for the products of multinational companies rises within China and manufacturing for export extends further into the interior. He also states that the Yangtze River system will continue to be the main arterial link between the interior and coast and that there will be "immense opportunities for freight carrying in other provinces such as Anhui, Henan and Sichuan, which still have relatively low levels of containerization." The author also states that while most investment are still concentrate in the Shanghai region, China's "Go West" policy is creating considerable interest in other regions further inland.

\section{BARGING CONTAINERS ON COASTAL AND INLAND WATERWAYS}

With the emergence of "hub ports" in ocean transportation, there is a growing interest in short sea shipping to move containers between ports both in coastal trade for a given economy and between economies. Concurrent with this is interest in improving the efficiency of moving containers from inland ports to the ocean ports and hub ports via short sea shipping. This has led to renewed interest in the role of barge transportation for container movements in inland water transport and short sea shipping which may possibly lead to a decentralization of hub port activity in the future. A study by the World Bank indicates that major seaports view, inland container terminals as competition. Smaller ports may profit by competing to be the point of entry and exit for the inland container terminals (ICT), which may lead to a certain degree of de-concentration..$^{24}$

Water transport has many distinct advantages over the other modes. Pinto (2001) notes that as routes are developed along existing rivers, canals and waterways, they don' $t$ have the problems associated with acquisition of "right-of-way" as in the case of road and rail.

\footnotetext{
24 World Bank, "The Evolution of Ports in a Competitive World," http://www.worldbank.org/html/fpd/transport/ports/toolkit/mod2.pdf
} 
He states that the cost per kilometer of waterway development is normally much less compared to that of an equivalent length (or capacity) of rail or highway and that the cost of maintenance for a waterway is also usually less than that of rail or road.

A vessel earns income by moving goods from one location to another. Time in port is costly so larger vessels need to unload their larger loads at fewer ports. From these hub ports, containers are carried to their final destination on various modes of transportation that may include rail (sometimes with containers double-stacked), trucks, and container barges. According to a recent industry report ${ }^{25}$ the energy requirement for a given amount of goods transported by water is substantially less than the alternatives of road and rail. Inland-waterway vessels need only about half as much energy to convey the same amount of goods as rail transport and only around a third as much as by road. A study by the American Waterway Operators Association shows that the distance one gallon of fuel moves one ton of cargo is 59 miles by truck, 202 miles by train and 514 miles by barge. A single 140-meter container barge can carry up to 470 containers or the freight capacity of 470 trucks. Examples of barges being towed, pushed, and carried are shown in Figure 6. The remainder of this paper will focus on barging of containers on inland and coastal waterways and the logistics and costs of doing so.

Figure 6. Methods of Moving Barges by Towing, Pushing, and Carrying

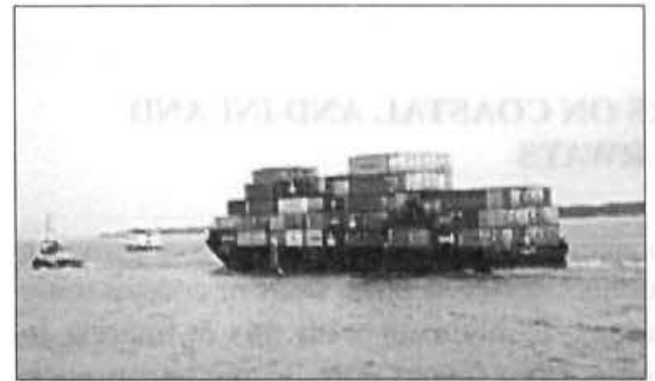

Source: Columbia Coastal Barge (2003)

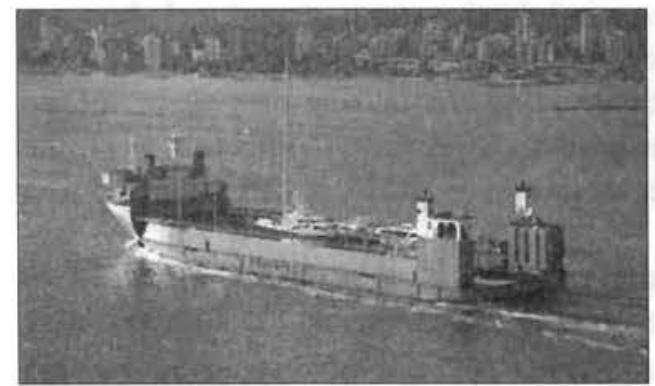

Source: Dockwise Yatch Carrier (2003)

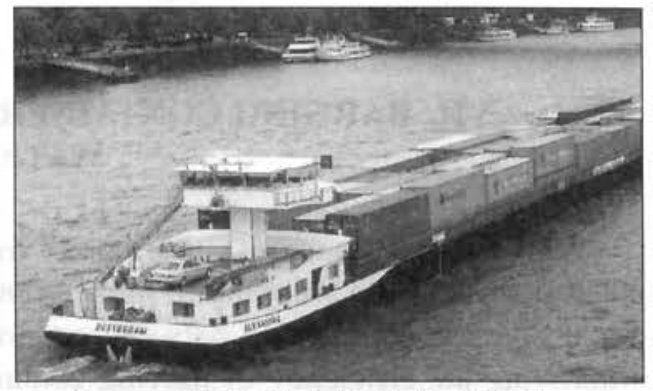

Source: MTU Friedrichshafen (2003)

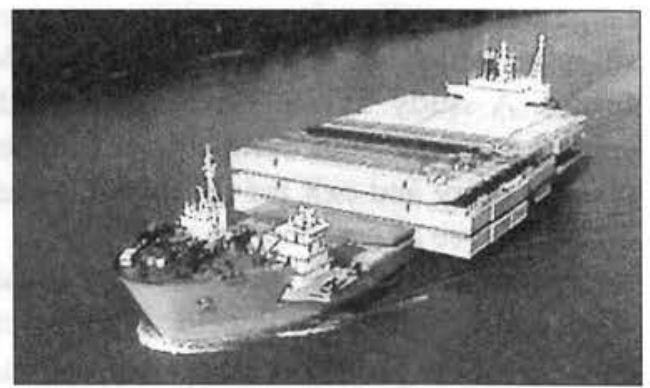

Source: Dockwise Barge (2003)

${ }^{25}$ MTU Friedrichshafen Report, Spring/Summer 2003.

http://www.mtu-friedrichshafen.com/en/th/pics/Rep1_03_Innen_eng.pdf 


\section{Container Barging In Europe}

According to a World Bank study, in Europe, the first inland container terminals appeared along the Rhine during late 1960s. Since then, on certain segments of the river, the Rhine has developed the largest amount of barge container traffic with some barges stacked up to 5 containers high. The port of Duisburg serves as a main inland hub for ports from Antwerp to Hamburg with the larger volumes going through the port of Rotterdam. Most of Europe's river container terminals offer tri-modal facilities, including direct access to rail transport and container stuffing and stripping facilities on the terminal. Rail plays an important role in distribution of cargo to destinations deeper inland. These inland terminals help relieve the seaport regions of congestion and function as satellites for seaports within Europe. The Rhine river system has approximately 35 barge terminals for handling containers. See Table 3 on barging containers in Europe. It gives an indication of the increase in barge operations from 1999 2003 showing different operators, the waterways, ports served and the service offered.

Table 3. Barging Containers in Europe

\begin{tabular}{|c|c|c|c|c|}
\hline Year & Country & Waterway & Company & Service \\
\hline 1998 & Belgium & Upper Rhine & Zeebrugge/Rhinecontainer BV & 16 barges, 250,000 TEUs Annually \\
\hline 1998 & Holland & $\begin{array}{c}\text { Uraniumcanal- } \\
\text { Amsterdam-Rhine } \\
\text { canal }\end{array}$ & Container Terminal Utrecht(CTU) & $\begin{array}{l}\text { daily shuttle service to Rotterdam with two } \\
24 \text { TEU barges }\end{array}$ \\
\hline 1999 & & & ECT Venlo & Duisburg and Willebroek \\
\hline 1999 & Holland & & Jan de Rijk & Roosendaal \\
\hline 2001 & Holland & Wilhelmina Canal & & Swedish Furniture Ikea \\
\hline 2001 & Holland & & Container Terminal Twente(CTT) & Hengelo \\
\hline 2001 & Holland & $\begin{array}{c}\text { Holland's smaller } \\
\text { waterways }\end{array}$ & $\begin{array}{l}\text { Participatiemaatschappij Mainport } \\
\text { Rotterdam(PMR) }\end{array}$ & Six 48 TEU barges 3 high \\
\hline 2002 & Germany & Weser & $\begin{array}{l}\text { Weser Mittellandkanal Container } \\
\text { Service(WCMS) }\end{array}$ & $\begin{array}{l}\text { Brunswick, Hanover, Minden and Bremen and } \\
\text { Bremerhaven with one } 60 \text { TEU barge weekly }\end{array}$ \\
\hline 2002 & France & Seine & Logiseine & $\begin{array}{l}\text { Paris(Gennevilliers), Rouen and Le Havre } \\
\text { with three sailings/week each way. Traffic } \\
\text { last year rose } 16.4 \text { percent to } 38,000 \text { TEU }\end{array}$ \\
\hline 2002 & France & River Oise & & Compiagne and Conflans Ste Honorine \\
\hline 2002 & France & & Logiseine & Rouen and Paris-Gennevilliers \\
\hline 2002 & Germany & & $\begin{array}{l}\text { Carl Robert Eckelmann Transport } \\
\text { and Logistik GmbH }\end{array}$ & Hamburg annual service of $100,000 \mathrm{TEU}$ \\
\hline 2002 & Germany & Rhine & Bargetrain $\mathrm{GmbH}$ & $\begin{array}{l}\text { Rotterdam/Antwerp to CXSWT's } \\
\text { Container Terminal Gemersheim }\end{array}$ \\
\hline 2002 & Belgium & Albert Canal & Riverliners Cobelfret & $\begin{array}{l}\text { Zeebrugge and inland centres such as Genk } \\
\text { with three } 500 \text { TEU barges }\end{array}$ \\
\hline 2002 & Switzertand & Rhine & Container Depot Frenkendorf AG & $\begin{array}{l}\text { three times/week sailing schedule with two } \\
220 \text { TEU barges }\end{array}$ \\
\hline
\end{tabular}




\begin{tabular}{|c|c|c|c|c|}
\hline 2002 & France & Rhine & Port of Strasbourg(PAS) & $\begin{array}{l}\text { Bassin du Commerce can accept barges } \\
\text { with containers } 4 \text { high }\end{array}$ \\
\hline 2003 & Germany & Rhine Hern Canal & Rhein-Westfalen Shuttle(RWS) & $\begin{array}{l}\text { Dortmund and the Ports of Rotterdam and } \\
\text { Antwerp. Currently } 5,000 \text { TEU with } 43,000 \\
\text { TEU projected }\end{array}$ \\
\hline 2003 & France & Seine & Champagne Atlantique River Line & $\begin{array}{l}\text { Le Havre and Nogentsur-Seine with } 10 \text { day } \\
\text { each way on } 96 \text { TEU barge }\end{array}$ \\
\hline 2003 & Holland & & Barge Terminal Tilburg(BTT) & $\begin{array}{l}\text { Currently } 70,000 \mathrm{TEU} \text { and } 280,000 \mathrm{TEU} \\
\text { projected }\end{array}$ \\
\hline 2003 & France & & Rhone Saone Conteneurs(RSC) & $\begin{array}{l}\text { Lyon, Macon and Chalon-sur-Saone with two } \\
132 \text { TEU barges and 19,000 TEUs annually. }\end{array}$ \\
\hline 2003 & Germany & Rhine & CSX World Terminals(CSXWT) & $\begin{array}{l}\text { inland container terminal at Germersheim } \\
\text { served by two } 400 \text { TEU barges }\end{array}$ \\
\hline 2003 & Holland & $\begin{array}{c}\text { Dutch Waterway } \\
\text { Network }\end{array}$ & $\begin{array}{l}\text { Mercurius Scheepvaart Groep } \\
\text { (MSG) }\end{array}$ & Served by 9 barges \\
\hline 2003 & Germany & Elbe & Trimodal Aken & Saxony Anhalt \\
\hline
\end{tabular}

Source: Compiled by author from various news sources (2003)

\section{Container Barging in the USA}

The economies of long-distance barge transport in the Pacific Northwest on the Columbia River versus land transport, has successfully transformed the inland movements of containers to and from the port of Portland. There are also successful container-on-barge services between Norfolk and Baltimore and between Houston and New Orleans as well as in other locations. ${ }^{26}$

The Port Authority of New York and New Jersey has started a new barge service for regional container transport between its marine terminals and the Port of Albany, NY. This program is designed to alleviate port and highway congestion, improve container handling and create sustainable environmental benefits by shifting cargo to new inland hub ports using all-water service. The inland hub port concept is not new but is an important development for U.S. ports. The port announcement stated "By shifting cargo volumes to inland hubs, ports are better able to address their mounting concerns about space limitations, improving efficiencies and safeguarding the environment. Essentially, the ports are able to grow and manage imports and exports more efficiently. The port authority stated that one of the primary goals of the cargo distribution network is to reduce the heavy reliance of port customers on trucks to move cargo. Currently, about $84 \%$ of the containers that come in or go out of the port are transported by truck. They said that when all of the ports are on line, the percentage of maritime containers moved by truck could be reduced to $57 \% .^{27}$

${ }^{26}$ Greater Houston Port Bureau, "Cargo Trax," The Bulletin, February 2000 edition, http://www.cargotrax.com/releases/archive/portbureaufeb2k.asp, November 13, 2003.

27 The Cargo Letter [384], “Air \& Ocean Logistics - Customs Broker News," 31 December 2002, http://www.interpool.com/tcl/cl_384.shtml 


\section{Container Barging in China}

As noted earlier, China has long been recognized as a leader in inland water transport, with one of the world's largest navigable waterway systems. There are a number of developments taking place that emphasizes the use of container barges on their coastal and inland waterways. For example, Frankel (1996) states that the Ningbo municipal government is planning on an integrated tug/barge system and routing schedule on the Yangtze River.

Along with this they have sponsored a macroeconomic demand analysis for their new transshipment hub that includes port planning, layout, and operational simulation.

Sinotrans and other shipping companies in China now offer inland barge service to hubs, where cargo is transshipped to ocean liners. Sinotrans currently operates 38chartered vessels (including barges) in its coastal and river feeder operations in the Yangtze River Area and the Pearl River Delta.

In the Yangtze River system they provide feeder services the ports of Nanjing, Zhenjiang, Nantong, Shanghai, Wuhu, Maanshan, Changshu, Wuhan, Anqing, Chongqing, Yichang and Jingzhou. In Jiangsu, they operate a container transportation service under the registered trademark "Sunny Express", servicing their customers' container transportation requirements between the Yangtze River Area and south to the Pearl River Delta. ${ }^{28}$ OOCL' s comprehensive network covers a total of 47 ports in China with dedicated barge services in the Yangtze and Pearl Rivers. ${ }^{29}$

Easton (2002) states that inland water transport for domestic distribution of goods is inexpensive, but it often is under utilized for a variety of reasons: Most ports lack the ability to process and manage cargo at international standards of efficiency. Shipping schedules are often are inflexible and delivery reliability is low. Intermodal operations often require multiple crane moves, which cause bottlenecks. Bureaucracy-related delays in customs processing occur routinely and pilferage and damage rates are higher than at most modern ports. Significant overcapacity exists, but many ports cannot accommodate larger cargo vessels. ${ }^{30}$

A report by World Cargo News (2001) states that container shipping on the Yangtze River, that stretches $3,700 \mathrm{~km}$ from Shanghai to deep in the south western heart of China has a number of problems. It suffers from shallow waters, red tape and old infrastructure. With regard to shipping by barge, the report states that booking can require lead times of up to a month and once cargo is loaded, it takes about five days to travel from Chongqing to Wuhan, eight days to Nanjing and 12 days to Shanghai. These distances are illustrated in Figure 5. Gan (2002) states that the Shanghai Region has 210 inland rivers with a navigable distance of $2,100 \mathrm{~km}$ and that while roads have been developing rapidly over the past 10 years, inland rivers have maintained about 23 per cent of the market share, transporting mainly fuel and bulk cargo.

\footnotetext{
${ }^{28} \mathrm{http}: / /$ www.sinotrans.com/About-Us/Our-Story/OurStrategy.shtml

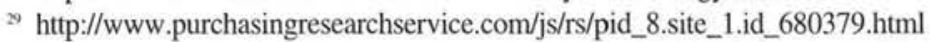

.00 Easton, Robert J, "On the Edge: The Changing Face of Supply Chain Management in China," Hong Kong, Accenture Supply Chain Management, 11/25/02, http://www.china-worldtrade.com/i/pdf/China_Supply_Chain_Perspectives_112502.pdf
} 
The problem is that only $275 \mathrm{~km}$ of the $2,100 \mathrm{~km}$ of navigable waterway allows boats above 300 tons. The infrastructure of many inland waterways in China is problematic. Swartz (1997) states that many have limited water-depth, width, insufficient lock dimensions and bridge heights that restrict container transport to stacking less than three levels. There are usually insufficient inland container terminals and barge berths, ports are not optimized for transshipment from inland waterways to other modalities resulting in inefficiencies and higher costs. Transshipment in sea ports from ship to ship, or from shore to barges, is still inefficient, time consuming, and expensive in many terminals.

Telecommunication and information systems are not sufficiently employed in inland water transport systems. Small shipping enterprises, operating one or two barges are not usually incorporated in cargo management networks and booking is not well developed in order to serve all shippers. China's Government however, is addressing many of these obstacles.

Easton (2002) states that in responding to these inland waterway infrastructure problems, China has recently invested US\$1.7 billion in inland water transportation, with the goal of developing an international-standard container network with intermodal capabilities.

In 2001, an agreement was signed between the Netherlands and China for a Yangtze River Basin project, designed to increase barge container transport in the region from $600,000 \mathrm{TEU}$ in 1996 to $9.5 \mathrm{M}$ TEU in 2010 . The intermodal system will eventually compriseWuhan, Jiujiang, Wuhu, Nanjing, Zhangjaigang, Nanton and Shanghai as central ports. Some 80 vessels, each with a capacity of $120 \mathrm{TEU}$, will feed the system. ${ }^{31}$

\section{Barge Network Design, Modal Shifts, and Logistics Considerations}

During the past decade, intermodal barge transportation has been the preferred way to ship containers and other commodities in Europe's inland waterways. These developments have taken place due to the cost/time advantage other that of road transport. The cost/time advantage however has room for improvement. Network design and application can have a big impact of the cost/time equation and are significant logistics considerations. The market and other system players also impact the performance of the system.

A general framework for barge network design has been developed by Konings (2003). This framework describes the design variables in relation to barge transport performance variables. These are quantitative variables that can be applied to various barge networks in various types of markets such as that in the Yangtze and Yellow Sea regions. Variables include: vessel size, transport volume, cooperation for sharing, frequency of service, and circulation times.

\footnotetext{
${ }^{31}$ Atas News, "Europe Presses For River Links," http://www.atas-trainmar.org/atasnews/ATASNEWS98.pdf , 20/09/2001
} 
Konings' framework is illustrated in Figure 7. In the case of barge vessel transits between Rotterdam and Duisburg, Konings calculated the indicative costs per TEU. It was based on three different barge sizes - 90 TEU, 208 TEU, and 398 TEU. The lowest cost for the 90 TEU barge was 25 Euro/TEU fully loaded. The 208 TEU vessel had the same cost per TEU loaded at $80 \%$ capacity (160 TEU), and the 398 TEU barge had the same cost per TEU loaded at $53 \%$ capacity (208) TEUs. The latter had the lowest cost fully loaded (398 TEU) at 12.50 Euro/TEU.

Figure 7. Framework for Barge Networrk Design

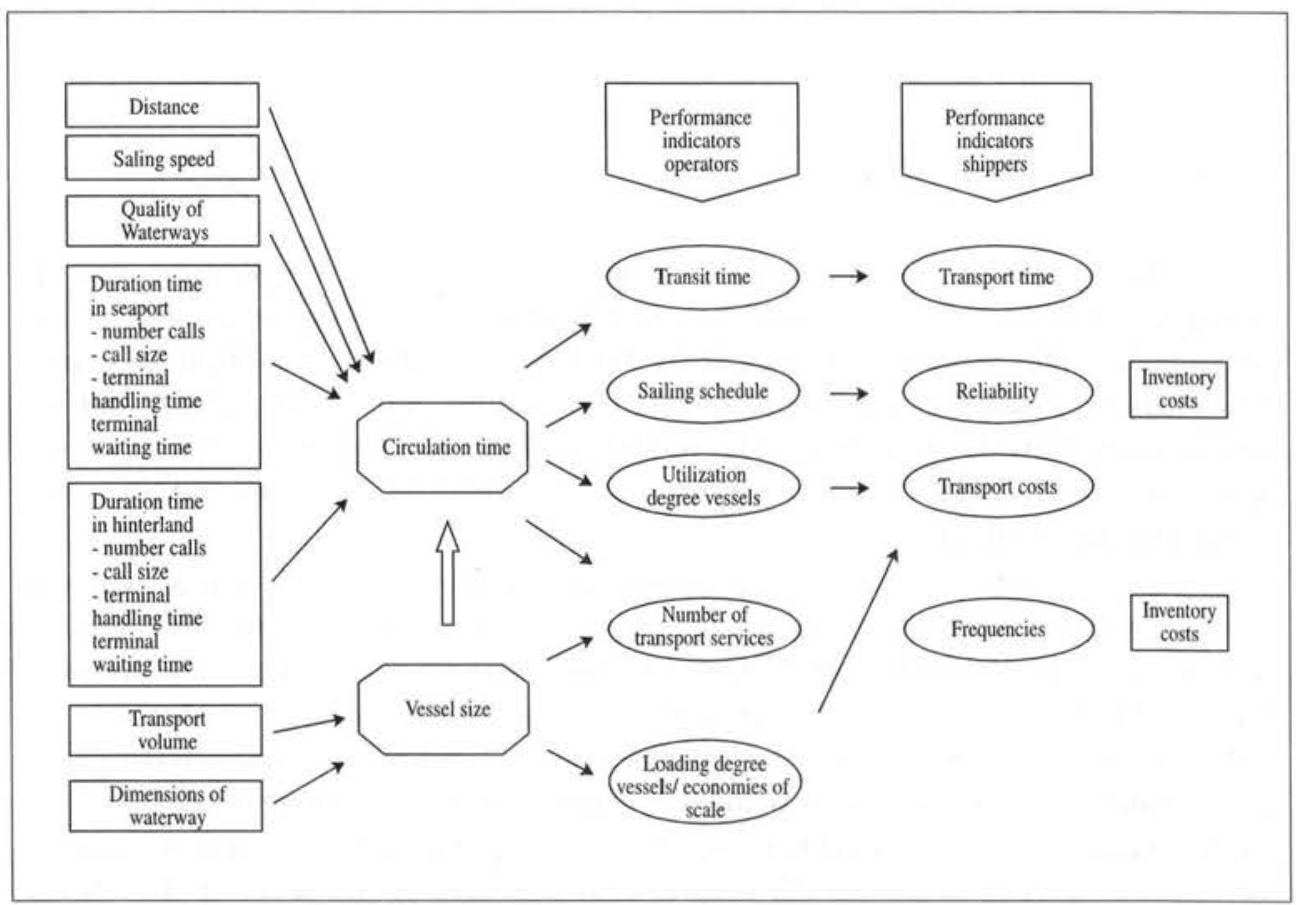

Source: TRB-Konings (2003)

Konings made another calculation using a 208 TEU vessel and looked at the frequency of service - $1,2, \& 3$ round trips per week. The more frequent service of 3 times a week using a 208 TEU barge had the lowest cost at 12.50 Euro/TEU. From these results, he came up with a generalized framework (Figure 8) that shows a network design based on transport market and waterway infrastructure along with barge circulation time plus barge size can influence barge transport performance. Logisticians can use these frameworks and attendant calculations to determine optimum conditions for container barge transport in other markets for coastal shipping and inland water transport. 
Figure 8. Generalized Framework for Barge Network Design

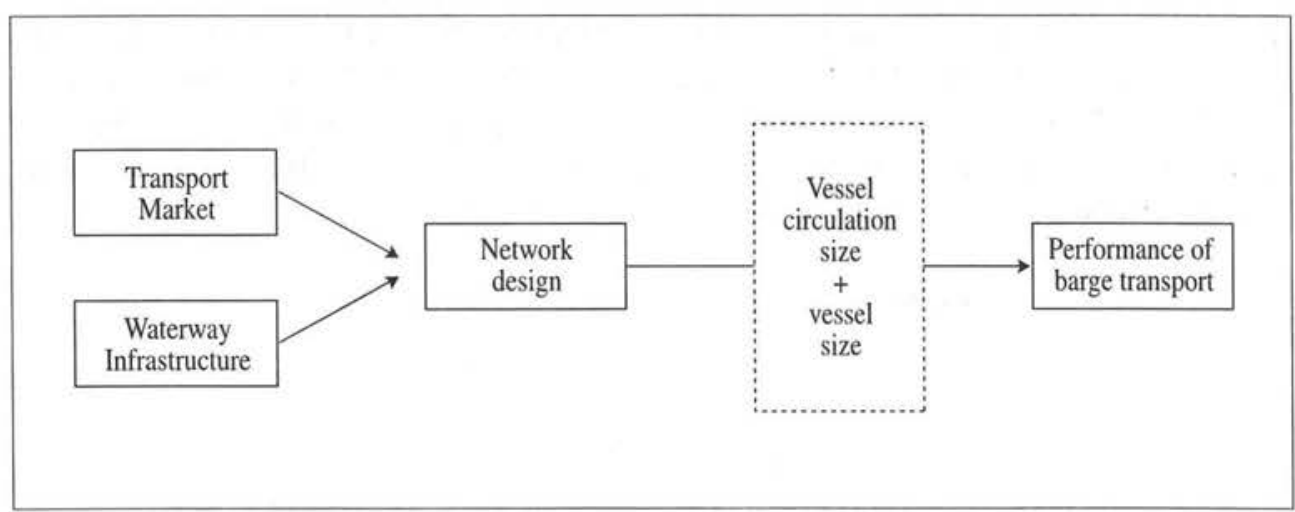

Source: TRB-Konings (2003)

Another cost model includes various modes (road, rail, inland waterway, sea) and intermodal transfer (marine terminals, rail terminals, and inland terminals) as cost components. This model as presented by Banomyong (2000) in a study at Cardiff University was adapted from work done by Beresford and Dubey (1990) and was improved by Beresford (1999). ${ }^{32}$ The model as shown in Figure 9 consists of four progressive stages from its basic form in (a), to intermediate stages (b) and (c), and to its final mature form (d).

The author states that "It is based on the premise that unit costs of transport vary between modes, with the steepness of the cost curves reflecting the fact that, for volume movements, sea transport should be the cheapest per ton-km, road transport should normally be the most expensive (at least over a certain distance), and waterway and rail costs should be intermediate. At ports and inland terminals, a freight handling charge is levied without any material progress being made along the supply chain; the cost incurred here are therefore represented by a vertical "step" in the cost curve. The height of the step is proportionate to the level of the charge. Depending on the route chosen, the combination of modes and cost will be different. The purpose is to find the most competitive route cost wise. The model may also be used as a contributory tool in the debate over the value of time in freight transport operations."

\footnotetext{
${ }_{32}$ Banomyong, Ruth, and Beresford, Anthony K.C., "Multimodal Transport Systems: The Case of Laotian Garment Exporters," Cardiff University, Department of Maritime Studies and International Transport, IMRL 2000 Third International Meeting for Research in Logistics, Trois-Rivieres, May 9, 10 and 112000.
} 
Figure 9. A Model for Multimodal Costs (Road, Rail, Inland Waterway, \& Rail)

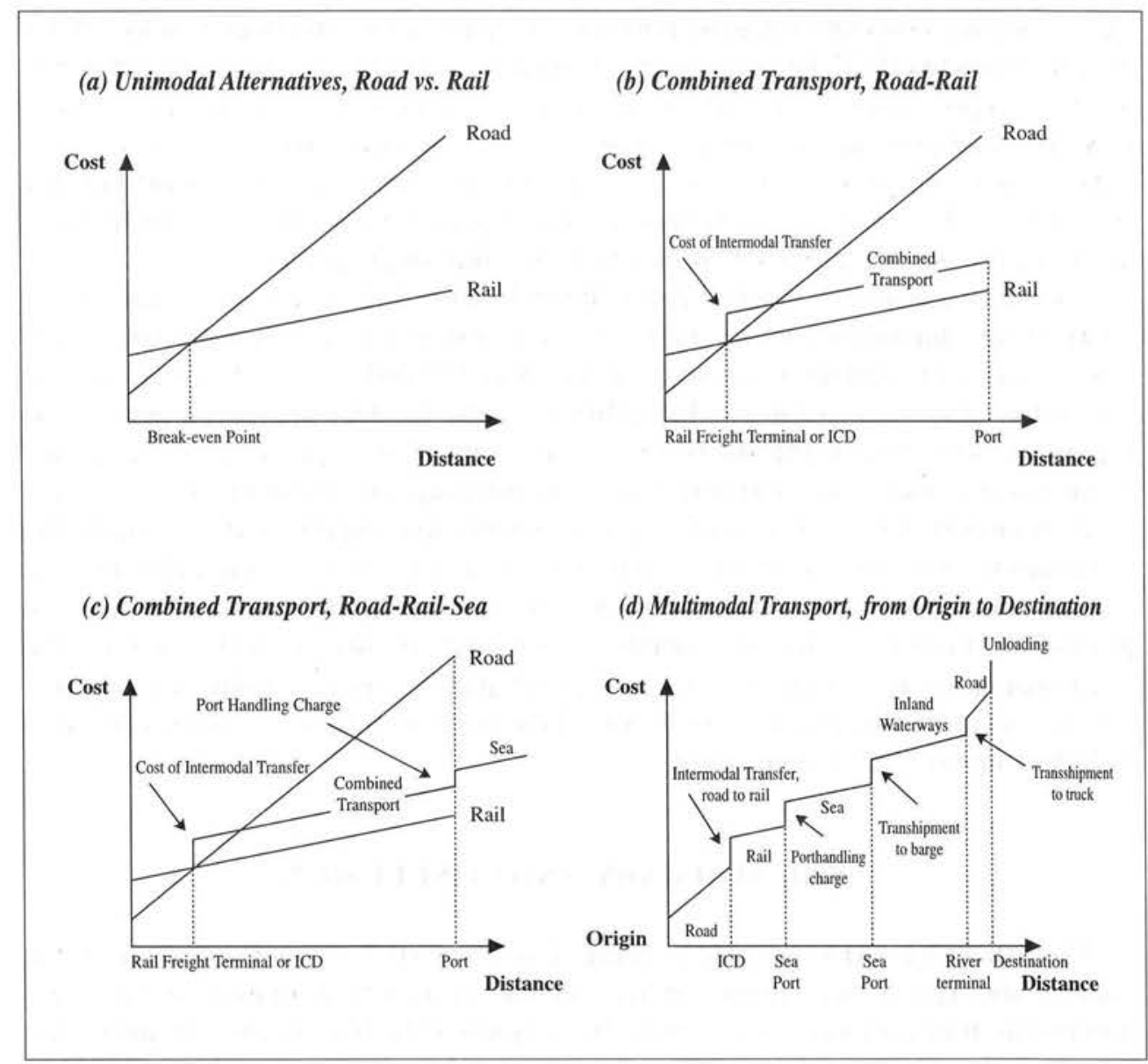

Source: Banomyong and Beresford (2000)

Both of the above models should be of great help to logisticians and others in determining the costs in shipping containers from point of origin to destination by various modes and various routes when inland or coastal water transport is used. The barge network design framework should be of specific interest in evaluating the conditions (transport markets and waterway infrastructure) that need to be considered in optimizing the best performance for barge operations given vessel size and frequency of service for the distance to be traveled.

The World Bank report states that the 21 st century will see radical changes in the port operations and that global competition will force changes in the way all players in the international logistics chain, including ports, do business in the future. It states that changes in distribution patterns will increasingly create a hierarchy of ports and that some historical port related activities would be shifted to inland sites. 
Ports are now looked at as a controllable element in improving the efficiency of ocean transport logistics which has generated a drive to improve efficiency, lower cargo handling costs and integrate port services with other components of the global distribution network. If the ocean transport industry is to remain competitive they will need to employ state of the art information technology (IT) to manage logistics networks, and ports in the future. Logistics service providers have great leverage in dealing with shipping companies, terminal operators and other port service providers. ${ }^{33}$ They make decisions that impact all parties involved in the supply chain, including port service providers as well as vessel and barge operators.

Container transport is mostly intermodal and Figure 9 illustrates the complexity of international shipments and the modal shifts or transfers that frequently take place. The logistics of container transport in the Yangtze and Yellow Sea regions and beyond is also very complex. In addition to the models presented above, the logistician needs to consider the broader system and all its supporting elements such as intermodal operations, infrastructure, rail, trucking, air transport, waterway and ocean transport, new technologies, systems integration, supply chain management, information systems, electronic commerce, contracts, just-in-time delivery, and security and customs, as well as education and research, plus ancillary service and production facilities. One also needs to consider the driver in the system, the "customer's needs" which includes service reliability, cargo visibility, tracking and tracing, accurate documents, cargo consolidation, and business logistics services including supply chain management.

\section{SUMMARY AND CONCLUSION}

This article has explored what is being done to promote economic growth in the Yangtze and Yellow Sea regions through the use of improved logistics services and waterborne transportation. This article has explored the barging of containers and how logistics along with modeling may be used to design, build, and operate intermodal transportation systems. It has looked at coastal and inland transportation in China and Korea, its growth and potential for continued growth. There are obstacles to growth of inland water transport, and while efforts are underway to solve some of the problems related to logistics and transport infrastructure a lot more needs to be done.

For the most part, this article has dealt with water borne container trade within and between China and South Korea although other modes are mentioned. Future work should provide a more detailed look at other the modes of transport as well as ports and inland waterways within and between the other economies of NE Asia - Japan, North Korea, Mongolia, and Russia. Of special interest would be the rivers of Northern China - the Tumen and Heilongjiang River systems, and the Harbin-Jiamusi channels of the Songhuajiang River.

${ }^{3}$ The World Bank, "The Evolution of Ports in a Competitive World," 
The shipping container has enabled the world to trade goods and materials on a scale that was unimaginable just a few decades ago. In order to accommodate the increase in container volumes an alternative to existing shipping methods is needed. Barging of containers should be given more consideration in short sea shipping, coastal shipping, and inland water transport as well as ocean shipping in addressing the needs of agencies, ports, shippers, carriers, and the consumer.

Serious consideration should be given to research in the design of container barges, terminals, and supporting vessels as well as logistics and the methods of moving container barges on intermodal shipping networks in the most efficient and cost effect way. These efforts could greatly promote sustainable economic growth in the Yangtze - Yellow Sea region with the Bo Hai area becoming the "economic engine" as envisioned by China and Korea becoming the logistics and business hub of the broader region.

Figure 10. Intermodal Transportation System

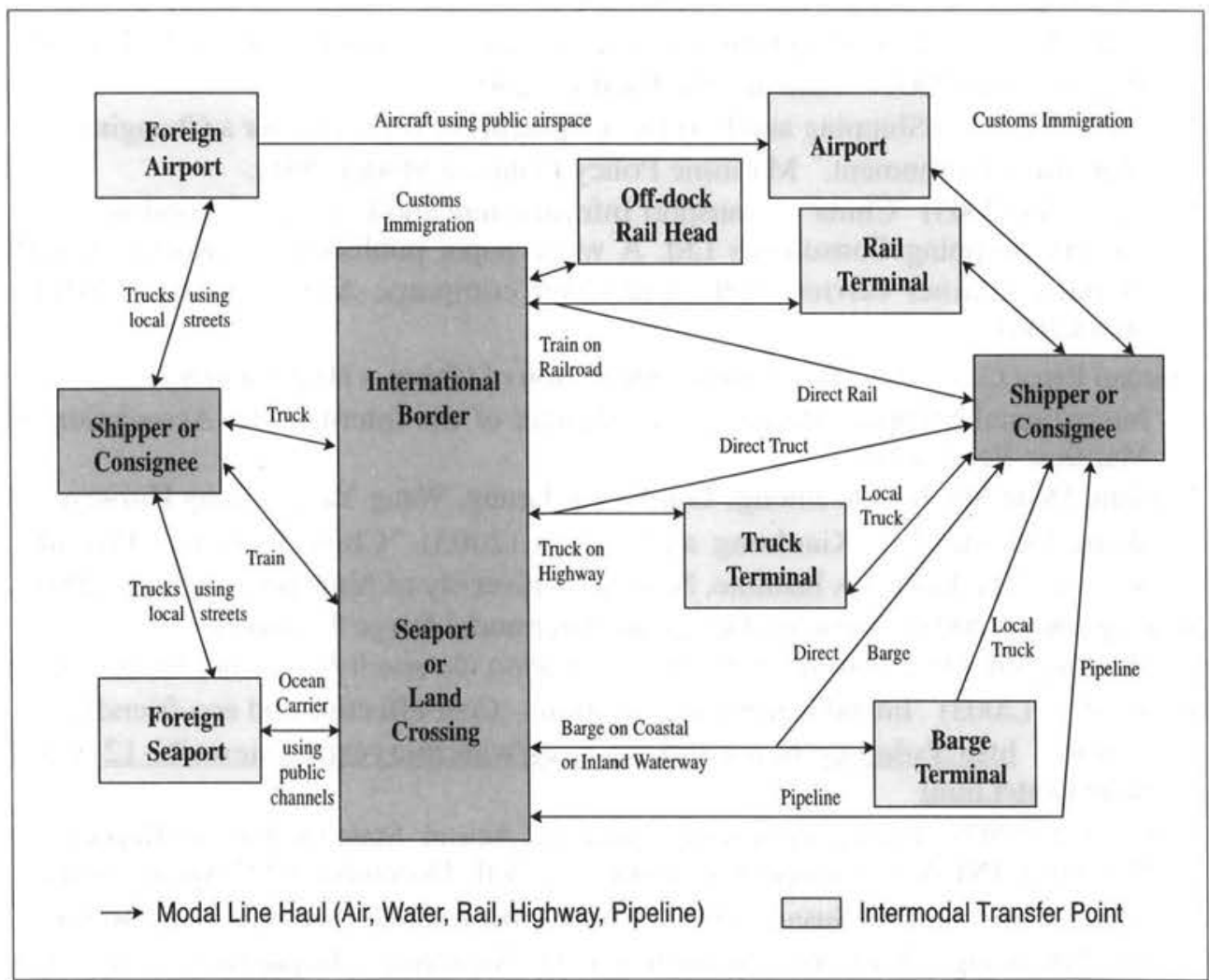

Source:

Redrawn from U.S. Freight: Economy in Motion 1998. Based on information from the Intelligent Transportation Systems and Intermodal Freight Transportation, Joint Program Office, Federal Highway Administration, November 1996; Intelligent Transportation Systems and Intermodal Transportation, Volpe National Transportation Systems Center, December 1996; Intermodal Freight Transportation and ITS. 


\section{REFERENCES}

Banomyong, Ruth, and Beresford, Anthony K.C. (2000) "Multimodal Transport Systems: The Case of Laotian Garment Exporters," Cardiff University, Department of Maritime Studies and International Transport, IMRL 2000 Third International Meeting for Research in Logistics, Trois-Rivieres, May 9, 10 and 11 2000.

Browning, Jesse (2003) "Development of Logistics and Transportation Systems in Promoting Trade \& Economic Growth: Comparing Incheon and Seattle Areas," Korean Observer, Vol. 34, No. 3 autumn 2003.

Chang, Young-Tae (2003) 'Korea's Strategic Plan to be Northeast Asia' s Logistics Hub: Towards the Pentaport Approach," Korean Observer, Vol. 34, No. 3 Autumn 2003 Shipping News, “Business Times,” Donald Urquhart, June 24, 2003.

Easton, Robert J. (2001) "On the Edge: The Changing Face of Supply Chain Management in China," Hong Kong, Accenture Supply Chain Management, $11 / 25 / 02$

ESCAP, "Review of Developments in Transport and Communications in the ESCAP Region, 1996-2001 -- Asia and the Pacific.” 2001

ESCAP, "Regional Shipping and Port Development Strategies Under a Changing Maritime Environment," Maritime Policy Planning Model, 2001.

Fossey, John (2003) “China' s Transport Infrastructure and Logistics," London:

Drewry Shipping Consultants Ltd. A white paper published in association with global container carrier, APL, and sister company, APL Logistics (APLL) $30 / 04 / 2003$

Frankel Ernst G. (1997) “Water/Road Integration of China's Hinterland to International Shipping Routes," An Abstract of the International Association of Maritime Economists.

Dai Jim, Deng Shi-Jie, Ou Jihong, Tsui Kwok-Leung, Wang Yang, Zhang Huiwen, Wang Derong, Liu Xiaohong and Li Rui (2003) "China Logistics Provider Survey," The Logistics Institute, National University of Singapore, January 2003.

Konings, Ron (2003) "Network Design for Intermodal Barge Transport,"

Washington, D.C, Journal of the Transportation Research Board, no. 1820, 2003.

Pinto, M. P. (2003) "Inland water transportation -- Cost-effective and eco-friendly option," http://sdnp.delhi.nic.in/resources/waterharvesting/news/bl-12-3-01inlandwater.html

Schwarz, J.(1997) "Inland Navigation Concerted Action: State Of The Art Report," Hamburg: INCATS, European Commission, VII, December 1997 Spear, Andrea;

Nailer, Chris; and He Susan (1997) “China Infrastructure: Sectoral Plans, Reforms and Financing," East Asia Analytical Unit, Australia's Department of Foreign Affairs and Trade, Briefing Paper Series No.6, JULY 1997

The World Bank, "The Evolution of Ports in a Competitive World,"

People's Daily, "Bohai Sea rim economic circle, a new economic engine," Beijing:

Interview with Wang, Yiming Deputy Director of China's State Development and Reform Commission, Macro-Economic Research Institute, October 04, 2003. 
Wang, Yang (2002) “China Logistics: Past, Present and Future,” Atlanta: Georgia Institute of Technology, 2002.

World Cargo News November 2001

Wu Ming (2001) "Blueprint for Transportation Sector: China Opens Transportation

Sector," August 15, 2001, http://www.chinese-embassy.org.uk/eng/16913.html. 